\title{
Economic Impacts of Adopting the Common Agricultural Policy of the European Union: A CGE Approach to the Case of Romania
}

\author{
S. Serban Scrieciu \\ The University of Cambridge
}

\begin{abstract}
This paper evaluates potential economic impacts of incorporating Romania into EU's Common Agricultural Policy. A CGE model of Romania is employed to model likely changes in trade, production and welfare patterns with a focus on fifteen local agro-food activities. Three main findings emerge. First, the adoption of the CAP expands agro-food output and trade, promotes higher farm incomes, and increases economic welfare. Second, CAP application results in production specialisation effects, particularly for sugar and sugar beet, bovine meat products, ruminant live animals, dairies, and cereal grains. Third, the identified impacts are driven by changes in trade-related measures, particularly enhanced access to EU markets, and less by alterations in production-related domestic support. The paper concludes that EU accession and CAP adoption may bring potentially realisable growth in Romania's agro-food sector, though in practice this will depend on producers' ability to respond to the supply incentives being offered.
\end{abstract}

- JEL classification: Q18, O52, C68

- Keywords: EU Eastern enlargement, Common Agricultural Policy, CGE model, Romania

\footnotetext{
*Corresponding address: S. Serban Scrieciu, Research Associate, Department of Land Economy, The University of Cambridge, 19 Silver Street, Cambridge, CB3 9EP, UK; Tel: +44(0) 1223 764868; Fax: +44(0)1223 337130, E-mail: sss38@cam.ac.uk 


\section{Introduction}

The eastward enlargement of the European Union (EU) and the extension of its Common Agricultural Policy (CAP) pose on-going challenges to both existing and incoming members. Romania (together with Bulgaria) signed its EU accession treaty in Luxembourg in April 2005 and is gained EU membership at the start of 2007. Accession negotiations officially started in February 2000, following Romania's submission for EU membership in 1995, and were concluded in late 2004. Advancing the restructuring process towards a market-oriented economy, which was initiated after the fall of the totalitarian regime at the end of 1989, represents a key issue for Romania in accelerating the pace of convergence towards EU performance levels.

This paper seeks to advance the understanding of the likely impact of CAP accession on the economic performance of Romania's agro-food sector, broadly incorporating all agricultural and food products produced or traded by the country, and grouped under major commodity headings. It applies standard Computable General Equilibrium modelling techniques to the specifics of the Romanian economy and to the new situation shaped by the outcome of negotiations on the agriculture chapter between EU and Romania. A particular feature of the modelling application is the stepwise approach to identifying and explaining the mechanisms through which CAP enlargement-induced policy changes impact domestic agrofood sectors.

Romania has been chosen as a subject of investigation in this paper for two main reasons. The first pertains to the scarce literature evaluating the potential impacts of Romania adopting the European Union's CAP relative to that addressing other Central and Eastern European countries that is currently available. This is more extensively revealed in the literature review section of this paper. The paper intends to fill this gap in the literature. The second reason relates to the timing of this paper with important policy implications. In other words, the results presented herein may contribute in a timely fashion to the building of a relevant evidence base and identify strategic areas of agricultural development for the country's policy making decision process at the start of the membership period. Furthermore, agriculture plays an important role in Romania's overall transition and development process. The sector distinguishes itself from both Central and Eastern European (CEE) and EU-15 countries through its sheer size in both absolute and relative terms, absorbing a substantial amount of human resources and producing a significant 
volume of the country's total output. ${ }^{1}$ Although Romanian agriculture is greatly under-developed, under-productive, and poorly integrated into marketing and trading structures, it does display a significant potential for development. Accession to the CAP may facilitate the process of agricultural development and may offer significant incentives for agro-food producers to move closer to their real production potential.

The next section of this paper provides a brief history of the CAP, whereas section 3 discusses its application to EU enlargement. Section 4 reviews the modelling literature dealing with CAP accession and identifies the research context within which the paper is placed. Issues pertaining to model and scenario formulation are summarised in section 5, while section 6 puts forward and explains the main modelling results. Section 7 concludes.

\section{Brief History of CAP Reforms}

The CAP emerged with the signing in 1957 by six EU original member states ${ }^{2}$ of the Treaty of Rome that created the European Economic Community and established the Common Market. It came into force in 1962 and at that time its main objectives were to boost agricultural productivity and increase agro-food production following the post world-war food shortages and the proliferation of rural poverty. The creation of the common market organisation for agriculture provided common competition rules and a common customs barrier against nonmember countries. Furthermore, the "dual pricing" system was introduced. This maintained internal European Community farm prices above world market levels, in order to provide adequate farm incomes and compensate for high production costs relative to those pertaining to other major agricultural producing economies (in particular, compared to developing countries). High EU internal prices for unprocessed and processed agricultural commodities were largely accomplished through three key instruments (Scottish Office, 1999): direct central intervention ("intervention buying") in the market if the market price falls below a guaranteed level; variable import levies to prevent imports from entering the Community at a

\footnotetext{
${ }^{1}$ For example, in 2000, agriculture in Romania contributed with $12 \%$ to GDP formation and employed $42 \%$ of the total active labour force, whereas the share of agriculture in GDP, and respectively, in total employment recorded $4.5 \%$ for the CEE- 12 and $2 \%$ for EU-15, and respectively, $22 \%$ for the CEE12 and $4.3 \%$ for EU-15 (EC, 2002).

${ }^{2}$ Belgium, Netherlands, Luxembourg, Germany (i.e. Federal Republic of Germany), France and Italy.
} 
cheaper price than the guaranteed price; and export refunds to allow member traders to sell competitively outside the Community at lower world prices, although they have locally purchased the agricultural products at a higher guaranteed internal price. Hence, the workings of the CAP go beyond the economics of a free trade agreement or of a customs union and entail, in addition, specific rules and government intervention mechanisms in influencing agro-food prices and farmers' incomes.

Although the objectives of increasing production and securing food supply at reasonable and stable prices for consumers were met, severe problems emerged, such as the dramatic increase in expenditures at the EU level, formation of huge and costly food stock surpluses, ${ }^{3}$ and augmenting environmental damage in rural areas. Furthermore, EU's "community preference" rule have been working against the principle of fair trade, permitting EU countries to dump subsidy-driven surpluses on the world market and depress world prices at which other producers (in particular from poor developing countries) could barely compete (Oxfam, 2002). As a consequence, a first large-scale reform of the CAP occurred in 1992 based on the MacSharry proposals that implied a transition from price/market support policies to more direct income support schemes. The package of reforms comprised significant cuts in internal guaranteed/support farm prices (particularly for beef and cereals), closing the gap between internal and world market prices, accompanied by compensatory income payments to farmers (known as direct payments), and the introduction of agri-environmental legislation that would encourage environmental friendly farming activities. In other words, the reform attempted to move away from market support, as a means of securing farm income, and shift the burden of support from the consumer, who pays the market price for the commodity, to the taxpayer, who pays for the direct payments, thus weakening the link between production and farm income.

Even though the 1992 reforms produced overall positive results in terms of reductions in food surpluses, increase in consumption and satisfactory movements in farm incomes, the CAP became confronted with new emerging challenges, both internally and externally (SER, 1996). Major external challenges were mainly represented by world trade liberalisation within the context of WTO negotiations (as other major agricultural exporters, in particular developing countries, argued for

${ }^{3}$ Food surpluses in the early 1990s were estimated, against a base of production required for EU selfsufficiency, at 30 percent for sugar, 21 percent for cereals, and 12 percent for butter (IISD, 1994). 
further reductions in CAP subsidies), the increase in global food demand, and the impending EU enlargement. ${ }^{4}$ This subsequently led to further changes in the CAP, namely the Agenda 2000 reforms, which mainly entailed further cuts in intervention prices for cereals, beef, veal and dairies, and the introduction of regulations related to rural development that created the so-called "second pillar". 5 The Agenda 2000 CAP reforms represented "a step towards supporting the broader rural economy rather than agricultural production, and ensures that farmers are rewarded not only for what they produce but also for their general contribution to society" (EC, 1999: 5).

Nevertheless, despite progress made with the reforming of the CAP, the proposed measures were yet insufficient to face the increasing pressures for change, in terms of further price cuts and less distorting farm support measures, particularly demanded within the world trade liberalisation context under WTO negotiations. After intensive debate, this resulted, in mid-2003, in a further reforming of the CAP and the decoupling of agricultural support payments from output decisions. The 2003 CAP reforms represented a landmark in EU's agricultural policy by addressing two key issues: creating a more market-oriented, simpler and less trade-distorting agricultural support system (in line with WTO requirements), and strengthening the rural development policy (EC, 2003a). The centrepiece of the 2003 CAP reforms was the single farm payment scheme that largely replaced the direct aid payments to farmers and severed the link between the majority of subsidies and the volume of production. ${ }^{6}$ This increased the bargaining power of the EU in subsequent WTO talks on agriculture, as decoupled payments shifted agricultural support from the trade distorting classification under WTO rules (the "red box") towards the minimal or non-trade distorting category (the "green box") (Kelch and Normile, 2004).

\footnotetext{
${ }^{4}$ Internal problems that further challenged the CAP included the gradual change in EU consumer preferences and concerns away from quantity and towards quality and food safety, the need for EU agricultural products to be more competitive, and the increasing concern for a clean environment and sustainable rural development.

${ }^{5}$ The Agenda 2000 reforms also included the fixing of a mandatory set-aside, the introduction of horizontal measures conditioning the granting of direct payments upon meeting certain standards in addition to cross-compliance (e.g. equal treatment of farmers), and the adoption of measures to enhance the quality of wine.

${ }^{6}$ Farmers may fully benefit from the single farm income payment provided that they comply with food safety, environmental and animal welfare standards, in addition to the cross-compliance rule that all farmland is kept in good agricultural and environmental condition (EC, 2003a).
} 
Despite the fact that the 2003 reforms have substantially geared the CAP towards more sustainable and less trade distorting European agriculture, the persistence of significant protectionist measures continues to be debated in the world trade context and still undermines the market-orientation of the farming sector. This is because the intervention mechanism continues to maintain EU prices above world prices, some amount of domestic support is still coupled to production, and market access and export subsidies have not been explicitly subjected to the respective policy changes. ${ }^{7}$ Nevertheless, the EU has been the only the WTO member to offer commitments to eliminate all its agricultural export subsidies, though only by 2013 .

\section{The Application of the CAP to EU Enlargement}

The eastward enlargement of the European Union together with on-going WTO trade negotiations have been the two most dominant pressing external factors for reforming the CAP. For instance, the Agenda 2000 reform of the CAP was adopted with the objective of facilitating the enlargement of the EU into Central and Eastern Europe and positioning the EU on a more favourable stand for agricultural negotiations under the WTO. In other words, concerns related to the high and unsustainable costs of extending the CAP to new members fostered the process of reform, particularly the adoption of Agenda $2000 .^{8}$

The eastward enlargement process has posed and continues to pose an unprecedented challenge to the EU and the CAP due its magnitude and diversity. For instance, EU enlargement in 2004 has been estimated to have added approximately 100 million new consumers to the EU market (reaching in total 500 million EU consumers), double the number of farmers governed by CAP regulations and increase the number of farms by 74 percent, while total GDP is predicted to increase by only around 5 percent (Pirzio-Biroli, 2002).

The new EU member states have adopted the EU legislation (or acquis)

\footnotetext{
${ }^{7}$ Lower export subsidies are expected with the reduction in intervention prices promoted by the latest CAP reforms. However, the reduction in subsidies will depend upon developments of the euro, i.e. a strong euro renders EU exports more expensive pushing subsidised exports close to WTO quantity ceilings (Kelch and Normile, 2004). Furthermore, Schroeer (2004a) argues that less than 50 percent of the value of EU's agricultural exports has been affected by decoupling. Nevertheless

${ }^{8}$ The CAP accounted in 2001 for over 50 percent of the EU's budget and spent around 40 billion euros a year on direct subsidies to European farmers (The Economist, 2002).
} 
pertaining to agriculture starting from the date of their accession, with the exception of limited (in time and in scope) transitional arrangements (EC, 2003b). Negotiations on the agriculture chapter between the ten new EU members and the former EU-15 were concluded at the end of 2002 (Copenhagen summit), whereas negotiations with Romania and Bulgaria were closed in mid-2004. Agriculture represented the largest of the negotiation chapters due to the complexity of CAP regulations and the important role that the EU has been assigning to the sector. Key agreements reached in negotiations, between the acceding countries and the EU, include direct income support or decoupled direct payments (through a phasing-in process), generous quota deals and rural development measures. In addition to these, several transitional agreements were concluded to allow the acceding countries sufficient time to adjust their agricultural production systems to meet EU food safety (sanitary, veterinary and phytosanitary) standards. Furthermore, recognition and protection has been granted to acceding countries for several geographic and origin brands. For instance, Romania was granted a three-year transition period for modernising a number of slaughtering and meat processing units, as well as milk processing establishments, an eight-year period for removing prohibited hybrid vine varieties and replacing them with EU accepted types of grapevines, and a recognition of several traditional spirit drinks, various milk-based products, salami and sausages, pies, bread and jams (Cionga, 2004). ${ }^{9}$

Finally, contrary to the phasing in of direct payments, the new member states benefit with EU accession from full and immediate access to other CAP support measures belonging to the first market pillar, such as intervention buying/ intervention prices for EU's sensitive agricultural products, border protection against non-members (e.g. common external tariff and export subsidies) and other market support payments that are paid at 100 percent of the EU level upon integration. ${ }^{10}$ Furthermore, with the implementation of the CAP, trade between new and existing members has been fully liberalised, providing full access for CEE

\footnotetext{
${ }^{9}$ However, products under transitional agreements are prohibited from being sold to other EU member states, thus limiting income opportunities for Romanian farmers and food processors.

${ }^{10}$ These represent subsidies paid to farmers or food processors that support the commercialisation of agriculture, e.g. dried fodder, flax/hemp and potato starch processing aid, and aid to producer organisations for delivery of tomatoes, citrus, peaches and pears for processing (Strossman, 2004).

${ }^{11}$ The liberalisation of trade has already taken place before accession for a number of agricultural products, under the so-called "zero-for-zero" agreements, whereby trade in agricultural products between EU and candidate countries is to be gradually liberalised based on mutual concessions.
} 
farmers to Western European markets. ${ }^{11}$ In addition, to take account of the entry of the new ten EU members, the CAP underwent further reforming to integrate the results of negotiations into the new acquis and to adapt the texts reforming the CAP.

Although the candidate countries and in particular Romania have succeeded in obtaining increased amounts of benefits to be granted to their farmers, ${ }^{12}$ it is unlikely that the concluded agreements alone will be sufficient to effectively contribute to either enhanced farm efficiency and better market integration or to significantly improved sustainable rural development prospects. Nevertheless, the new EU members are likely to significantly benefit from the CAP in terms of increased agricultural output, and a boost in agricultural prices and farm income. For example, the outcome of agricultural negotiations in the case of Romania, if supported by an adequate domestic institutional framework seem to favour the development of five strategic areas, namely rural development, cereal grains and feed crops, cattle breeding, wine-growing and wine-making, and food processing (particularly sugar and dairy production) (Ciupagea et al, 2004). However, in order to evaluate to what extent new EU members may benefit or not from adopting the European Union's CAP, quantitative investigations are necessary. These are addressed in the following sections.

\section{Literature and Context}

Although considerable research efforts have tackled in the past decade various aspects of CAP reforms and their implications for existing EU members (Philippidis and Hubbard, 2003, Lips and Rieder, 2005), assessing the impacts of CAP accession on the performance of agriculture in transitional and EU candidate countries has also received its share of attention and analysis. The most widespread methodology employed in the literature for this type of applied policy investigation is represented by the simulation approach, particularly Computable General Equilibrium (CGE) modelling. The CGE modelling approach has become a widely accepted and increasingly deployed methodology for the ex-ante assessment of the economic impacts of changes in policy variables. This is largely because CGE

\footnotetext{
${ }^{12}$ According to negotiation outcomes, Romania is expected to receive a total financial package for agriculture of 4 billion euros over the period 2007-2009 (plus around 800 million euros estimated financing from structural funds), which represents the equivalent of twice the budget of the Ministry of Agriculture for 2004 (Ciupagea et al, 2004).
} 
models represent a powerful, flexible and useful analytical and simulation device for distinguishing between the multiple effects that might be brought about by the implementation of a set of related policy measures, such as those induced by the EU enlargement process (FAO, 2003). Their main advantage relative to some other methodological approaches (e.g. partial equilibrium models) is their capacity to address the workings of an economy in an integrated manner, and to consider the complex inter-linkages between all the sectors and economic agents of an economy. Nevertheless, for example, the partial equilibrium approach performs better when it comes to modelling detailed policy measures that require a more detailed, disaggregated and explicit analysis (such as the price intervention mechanism which in the CGE approach employed in this paper is only implicitly modelled). For this reason some references to partial equilibrium modelling (PEM) studies are also made in this section.

CGE studies investigating the impact of extending the CAP to candidate economies may be classified into two broad categories. The first category consists of those that treat the CEECs as a single entity (e.g. Hertel, Brockmeier and Swaminathan, 1997, Liapis and Tsigas, 1998, Jensen, Frandsen and Bach, 1998, Frandsen, Jensen and Vanzetti, 2000, and Herok and Lotze, 2000). The second category evaluates the effects of CAP accession for particular CEE countries (e.g. Bojnec and Münch, 2001, for Slovenia, and Cochrane and Seeley, 2004, for Poland, Hungary and Czech Republic, both using a PEM approach; Fuller et al, 2002, for Czech Republic, Poland and Hungary, Brockmeier et al, 2003, for the twelve accession countries, Jensen and Frandsen, 2003, for the ten first-wave accession countries, and Banse, 2003, for ten CEE countries including Romania and Bulgaria, all using a CGE approach, except for the latter that uses a combination of both). In general, studies in the first category chronologically preceded studies from the second category. ${ }^{13}$

Though the estimated results of these different modelling studies may partly depend on the type of modelling techniques, assumptions and scenarios employed, an important overall conclusion emerges from this body of literature, namely a convergence towards similar findings at least in relation to the overall direction of the estimated effects. There is a consensus view that the implementation of the CAP in the CEE region will increase producer prices and farm income, and

\footnotetext{
${ }^{13}$ This is because most of studies belonging to the first category employed the GTAP database, which at the time they were undertaken displayed data for the CEE region as a whole and not on a country-bycountry basis.
} 
encourage agricultural growth in these countries. As trade impediments ${ }^{14}$ are eliminated, CEE production and exports increase in the agricultural sector at the expense of non-agricultural sectors, farmers benefit on average from higher support, and production factors are increasingly attracted in those agro-food activities mostly supported under the CAP umbrella. Furthermore, overall economic welfare improves as the CEE benefits from substantial financial inflows from the CAP budget and better terms of trade, and the accession countries become more specialised in agricultural production and produce more of the world's supply. Therefore, there seems to be a common view that an eastward expansion of the EU and CAP would be beneficial to the CEE candidate countries, at least in terms of improved prospects and incentives for the development and increased specialisation of agriculture.

However, estimated relative changes in the disposition of agro-food output tend to differ across CEE countries, partly because these are driven by heterogeneous and country-specific differences in initial protection rates and in the importance of each sub-sector in total production and trade. For instance, the Brockmeier et al (2003) CGE study finds that cereal grain production tends to decrease with EU accession in Slovenia, Czech Republic and Latvia, and increase in other CEE countries, such as Malta, Bulgaria, Hungary and Slovakia, whereas cattle production increases and raw milk output is quota-restricted in all accession economies. Bojnec and Münch (2001) use a partial equilibrium model and find that the Slovenian adjustment to the CAP will not significantly boost producer prices or expand agricultural output in comparison with other candidate countries. This is attributed to the very narrow gap between farm-gate prices in Slovenia and EU, and to the higher wholesale and processing prices in the respective accession country than the EU. Cochrane and Seeley (2004) also adopt a PEM approach and find that output of feed grains and beef is expected to significantly increase in Poland, Hungary and Czech Republic. The Jensen and Frandsen (2003) CGE study estimates that wheat and other cereal grains will experience output growth, especially in Hungary, Poland and Lithuania, whereas the production of bovine and other meat products is likely to increase particularly in Poland and Hungary. Detailed findings pertaining to the agro-food production and trade structure of a specific country may not necessarily apply to that of another CEE economy and for

\footnotetext{
${ }^{14}$ In addition, the removal of trade impediments in the EU will not only enable competitive producers from CEE countries to undercut their EU competitors but might also increase their productivity as capital and technology flows towards new members increase (Frandsen et al, 2000).
} 
this reason, undertaking single-country CGE studies to evaluate changes in output and trade patterns due to CAP adoption within a given candidate economy are needed. Nevertheless, the overall aggregate agro-food output and trade growth response tends to be a common finding for most CEE economies, including Romania (as revealed in this paper). In other words, though aggregate responses of the agricultural sector to CAP adoption may be typically extended to other EU candidates, the disaggregate impacts tend to be country specific.

Moreover, studies separately considering general equilibrium effects of CAP enlargement on Romanian agriculture are extremely sparse. Brockmeier et al (2003) and Banse (2003) take account of accession effects within multi-country modelling frameworks that include Romania and Bulgaria amongst the rest of CEECs. The first study is however limited in providing a representative picture of the accession impacts on agriculture in Romania. This is because it was undertaken before agricultural negotiations between EU and Romania were actually concluded and makes two main assumptions under which the CAP will be extended to Romania (and Bulgaria). First, direct payments are extended to Romania based on figures for all other candidate countries, and second, the allocated quotas are assumed to be binding future production levels. However, Romania has obtained milk and sugar production quotas that are not actually binding with EU accession and, consequently, growth is expected to occur in these activity areas. Banse (2003) provides a more complex analytical approach by combining CGE models with partial equilibrium models. Nonetheless, the author's analysis was also undertaken before negotiations on agriculture between EU and Romania were concluded and consequently merely extends the negotiation outcomes from the first-wave to second-wave candidate countries.

Nevertheless, there are several limitations of the CGE methodology that are worth emphasising. First and foremost, the "black box critique" is often forwarded to argue against the approach. This generally refers to the failure of modellers to clearly state the assumptions, explain the workings of the model and the underlining transmission mechanisms, and describe how modelling results are actually derived. Second, model behavioural parameter estimates are borrowed from other sources or deterministically obtained, rendering CGE models difficult to validate in the traditional econometric sense. The third shortcoming applies to comparative static models that particularly address transitional economies. This relates to the so-called "transition handicap", namely their failure to account for the dynamic development of countries in transition over longer periods of time that are 
not yet on their steady state growth path and are still likely to undergo rapid and substantial changes (Piazolo, 2001). Furthermore, the non-inclusion of dynamic effects overlooks dynamic gains from trade and capital accumulation. Fourth, due to their numerous assumptions and uncertainties general equilibrium models, and in particular their static variations, are very limited in dealing with structural constraints and providing meaningful insights with reference to the adjustment process as a whole from one point of equilibrium to another. ${ }^{15}$

The CGE model that is developed in this paper and its associated results are also subject to these limitations, though the "black-box critique" has been largely addressed by providing a clear and concise display of scenario formulation, and a step-wise presentation of simulation results that gradually build up to the final scenario of incorporating Romanian agriculture into EU structures. Though the results need to be seen within this limiting context, the CGE modelling approach is capable, however, of providing useful insights into potential shifts in agro-food output and trade patterns triggered by the EU enlargement process and the adoption of the CAP, with important policy implications for agricultural development.

This paper applies a single-country static CGE model and focuses on the economic impact of CAP accession on Romania's agro-food sectors. It uses recent final negotiation outcomes on agriculture between Romania and EU to provide a more reliable estimate of the likely effects of CAP accession, both at an aggregated and disaggregated sub-sectoral level.

\section{The CGE Model for Romania}

The benchmark database for the model is a Social Accounting Matrix (SAM) of

\footnotetext{
${ }^{15}$ For a review of the inherent limitations that CGE models encounter when undertaking policy appraisal, and dealing with more complex issues, such as sustainability, dynamics and transition paths see Scrieciu (2007).

${ }^{16}$ This has been derived by pursuing a series of alterations to a SAM for Romania developed in Banse (2001) in order to meet this paper's research objectives: a re-classification of commodity groupings so that the model focuses on the agro-food sectors in detail and less on manufactures or services; the addition/separation of land as a primary factor input to agricultural production activities; the disaggregation of Romania's trading partners into four main groups (the fifteen European Union members, EU-15, the ten Central and Eastern European Countries, CEEC-10, Bulgaria, and the Rest of the World, RoW); the transfer of intermediate consumption of services to the intermediate consumption of raw milk and sugar beet associated with the production of dairy and sugar products; the modification of any negative entries for the value added of capital to reflect positive numbers; and the employment of the RAS (Random Allocation Sampling) technique to balance the SAM.
} 
Romania based on 1997 data. ${ }^{16}$ There are twenty-three production sectors in the model: eleven primary agricultural activities (wheat, other cereal grains, vegetables/fruits/nuts, oilseeds, sugar beet, plant-based fibers, other crops, cattle/ sheep/goats/horses, other animal products, raw milk, and wool/silk-worm cocoons), one sector producing other primary products, seven food-processing sectors (bovine/sheep/goats/horse meat, other meat products, vegetables oils/fats, dairy products, sugar, other food products, and beverages/tobacco), three manufacturing activities ${ }^{17}$ and one overall services sector. This type of commodity grouping or sectoral classification renders the model suitable for a more detailed analysis of impacts on agriculture at the sub-sectoral level. In addition, the economic assessment also focuses on several major downstream food-processing sectors, mainly because of the strong economic inter-linkages between primary and processed agricultural activities, and the fact that CAP measures target both agricultural and processed food commodities.

\section{A. Model formulation}

The representation of production in the model has been stylised following standard structures in the CGE modelling literature. Producers maximise profits subject to a constant returns to scale production technology and operate under perfect competition settings. Each production sector displays a nested production function structure, with a Leontief technology at the top level aggregating value added and a composite intermediate input. A linear-homogeneous Constant Elasticity of Substitution aggregator function allows for substitution between factors of production. The latter are fully mobile, excepting land that is specific for the agricultural sector as a whole, though at the sub-sectoral level it is allowed to shift from one farming occupation to another. Moreover, resources are not fully employed and factor supply is endogenised by allowing for factor unemployment. A Phillips (factor return) curve inverse relationship is assumed between the rate of unemployment and real returns to the factor under consideration. ${ }^{18}$ Hence, factor markets are closed by changes in factor unemployment levels, whilst factor supplies are made endogenous.

\footnotetext{
${ }^{17}$ These consist of textiles/wearing-apparel/leather, machinery/equipment/transport means, and other manufacturing products. The manufactures group is split into these three sub-groups because it is best to keep some level of disaggregation among major commodities that are intensively traded in order not to lose important information through aggregation and to better portray general equilibrium economic impacts.
} 
A "double Armington" assumption on bilateral trade streams is employed in order to differentiate products according not only to their region of origin (the original Armington assumption shaped by elasticity of substitution values) but also to their market destination (shaped by elasticity of transformation values).$^{19}$ These apply in a two-stage manner sometimes referred to as a "two-tier decision process" (Donnelly et al, 2004). First, domestically produced goods are differentiated from imports, and goods produced for domestic use are differentiated from exports. Second, imports and exports are imperfect substitutes across the four foreign trading regions. The Armington assumption solves the problem of cross-hauling encountered in trade data, which under perfect competition is inconsistent with traditional Hecksher-Ohlin trade theory (Petersen, 1997) ${ }^{20}$ Furthermore, Romania is modelled as a small country, reflecting its inability to influence world prices by altering its trade position. The terms of trade faced by the small country thus do not change in the baseline (Södersten and Reed, 1994).

The representative private household receives income from its supply of factors of production, from transfers from abroad and from the government, and maximises utility given by a Cobb Douglas function having as parameters private consumption and private savings subject to its budget constraint. ${ }^{21}$ The government collects its revenue from applying taxes (import tariffs, production taxes, and directs taxes) and from appropriating its rent raised on government owned capital,

\footnotetext{
${ }^{18}$ This represents a standard way of accounting for unemployment. In order to compute the employment conditions for the factors of production, an elasticity of unemployment with respect to pay of -0.1 is assumed for all primary factor inputs. This was derived from the literature that econometrically estimates wage curves and the corresponding elasticities for countries in transition. For example, Kállai and Traistaru (1998) suggest the presence of a wage curve in Romania and estimate a significant elasticity of unemployment to pay of -0.13 for 1993 and 1994 . Walsh and Duffy (2002) find a local unemployment elasticity of pay for Poland of -0.1 over the period 1991-1996. Finally, Blanchflower (2001) estimates East European wage curves over the period 1990-1997 that produce a local unemployment elasticity of between -0.1 and -0.3 .

${ }^{19}$ The use of the double Armington approach and the introduction of product differentiation across market destination according to constant elasticity of transformation supply functions is justified by the fact that Romania's exports to industrialised countries tend to be of a higher quality and standards than those targeting the domestic market.

${ }^{20}$ The double Armington assumption is necessary in order to avoid an unrealistically high degree of specialisation.

${ }^{21}$ The household's budget constraint also accounts for a lump-sum transfer to the government (representing direct taxes), capital depreciation and changes in inventories (the household is also a capital and firm owner).
} 
which is then spent for government consumption purposes, government investments (savings), and on transfers to the household. However, for model closure purposes, government consumption is held fixed and only transfers to households change with budgetary income fluctuations, accounting for the existence of a budget imbalance. The adoption of this rule is largely supported by the fact that government consumption is usually taken to reflect mostly decisions of policy makers rather than any specific economic mechanism (Zalai, 1998). The second main closure rule is a macroeconomic neo-classical closure where investments are endogenous and adjust to accommodate changes in savings. ${ }^{22}$ This allows for the existence of a trade deficit and helps to solve for the fundamental indeterminacy of investments in comparative static models. ${ }^{23}$

\section{B. Scenario formulation}

Based on the structural characteristics underlining the 1997 SAM database, the model performs a comparative static analysis associated with two equilibrium outcomes induced by two scenarios, namely alternative ("accession-on") versus baseline ("accession-off"). The baseline scenario is constructed over a fifteen-year period (1997-2011), makes a series of assumptions regarding macro-trends in the absence of the country's EU integration, and estimates accumulated changes over the respective time-frame. The alternative scenario assumes in addition to the baseline scenario that Romania does join the European Union in 2011, and evaluates changes in endogenous variables relative to the baseline. ${ }^{24}$

Both scenarios are formulated with consideration to three major external factors: the implementation of Agenda 2000 and 2003 CAP reforms, the first wave of EU

\footnotetext{
${ }^{22}$ Thus, the trade balance in foreign currency is exogenously fixed so that any change in investment is financed out of national savings.

${ }^{23}$ However, investments in a static model only influence aggregate demand and do not impact productive capacities or the availability of capital within the national economy.

${ }^{24}$ The $2011 \mathrm{EU}$ accession date represents a modelling artefact. This is because the impacts of enlargement take effect starting from the actual scheduled time of accession in 2007 and require a certain time of transition to adjust to the new environment and to the new steady-state equilibrium. Hence, in order for the static effects of enlargement to take account of the adjustment period, the model implicitly allows for a transition period of five years starting from the expected time of accession (2007) for the economy to reach the medium to long-term new equilibrium (2011) projections. Furthermore, EU accession does not happen overnight and the economy is to a certain extent prepared some time in advance for the respective integration event, thus giving the economy more time to adjust to and reach the medium to long-term modelling projections.
} 
enlargement (2004) that included ten CEE countries (CEEC-10), and the likelihood that Bulgaria will also join the EU in 2007. Assumptions shaping the baseline scenario consist of developments in real GDP growth rates,${ }^{25}$ the liberalisation of trade in manufactures/services between Romania and EU-25 members, a 2004 update of border protection levels on trade flows in agro-food commodities between Romania and its trading partners (also reflecting the realisation of CAP reforms) ${ }^{26}$ and changes in domestic support measures forwarded by the Romanian government. ${ }^{27}$ The formulation of the alternative accession scenario draws on the outcome of negotiation talks on agriculture between Romania and the EU concluded in mid-2004. The accession scenario is associated, therefore, with the implementation of a bundle of CAP policy measures to the Romanian case. It consists of the full liberalisation of agro-food trade between Romania and EU-26 (providing full access for Romanian agricultural producers to Western European markets) ${ }^{28}$ partial access to EU's reformed direct income payment scheme, ${ }^{29}$ and full and immediate access to other CAP support measures belonging to the first market pillar, i.e. intervention buying for EU's sensitive agricultural products, border protection against non-members (e.g. common external tariff and export

\footnotetext{
${ }^{25}$ Baseline economic growth is assumed to record an annual average increase of 3.2 percent over the period 1997-2011 of actual and projected real GDP growth rates (NBR 2004 and Government of Romania 2004).
${ }^{26}$ The adjustment in EU (including the CEEC-10) import ad-valorem tariff equivalents and export subsidies is mainly based on the calculated projections provided in Jensen and Frandsen (2003) that take into account the proposed cuts in intervention prices according to the Agenda 2000 reforms. Border protection modelling projections do not include the recent Doha Development Agenda proposals and any likely alterations in WTO commitments.
${ }^{27}$ Market price support, representing the bulk of domestic support, has been implicitly taken into consideration in the baseline scenario through the 2004 update in import tariff rates. The remainder have mainly consisted of payments based on input use since the start of reforms (1990) until 2001, when they have been largely replaced with payments based on area planted (equivalent to the direct payments practised by EU). This latter policy change is reflected in the baseline by the introduction of direct payments financed from national budgetary resources and the elimination of other forms of domestic support. Payments granted by the Romanian government based on area planted/animal numbers are computed based on 2001 data from OECD (2002), when they represented around 2.5 percent of the total value of production.

\footnotetext{
${ }^{28}$ This refers to the elimination of both tariff and non-tariff barriers between EU-26 and Romania. Nontariff barriers that consist of border costs (customs and fiscal control) and technical barriers to trade (harmonisation of standards) are assumed to amount to 2.7 percent of the total value traded. The estimation follows other studies focusing on the enlargement effects for other Central and Eastern European countries, such as Maliszewska (2002) and Piazolo (1999) (i.e. 1.7 percent for border costs plus 1 percent for technical barriers to trade).
} 
subsidies) and other market support payments that will be paid at 100 percent of the EU level upon integration. ${ }^{30}$

Three caveats apply here. First, intervention buying and the market price support system promoted under the CAP are only implicitly modelled through changes in border protection. Second, the agreed milk and sugar quotas seem not to pose constraints for likely EU accession-driven output growth. ${ }^{31}$ In other words, agreed quotas are unlikely to be binding at the time of accession, enabling the milk and sugar production to expand to their existing potential. Third, rural development measures and structural funds are not included in this particular modelling exercise. This is because funds, such as those targeting rural development, are difficult to explicitly model as these may be used for various purposes, e.g. environmental protection, restructuring of agricultural units, product quality enhancement, support to subsistence and semi-subsistence farms, support to young farmers, the creation of alternative employment opportunities, and so on. However, welfare and budgetary effects resulting from the adoption of CAP market (trade and domestic

\footnotetext{
${ }^{29}$ The paper assumes that Romania follows the example of other CEE countries that joined the EU in 2004 and adopts the simplified version of the single farm income payment, namely the Simplified Area Payment Scheme (SAPS). Under this scheme, direct payments represent a flat rate subsidy that is paid on a per-hectare payment (farm size) regardless of production volumes and irrespective of the type of crops grown or if any crops are produced at all. According to negotiation outcomes, the homogenous land input subsidy is implemented only in the first three years after integration, when the payments will gradually reach 35 percent of the EU level, after which Romania is supposed to revert to the fully decoupled scheme (Schroeer, 2004b). The respective subsidy is thus computed by augmenting the first instalment of direct payments agreed for Romania representing 25 percent of the EU-15 level (405 million euros according to Ciupagea et al, 2004) to reach 35 percent of the EU-15 level (567 million euros) and then dividing the respective amount by the total value of farm production evaluated at producer prices averaged for 2000-2002 period (9618 million euros, according to NIS, 2004). This results in a flat land input subsidy rate of 5.9 percent that all farmers receive from the EU budget.

${ }^{30}$ Other forms of domestic support still coupled to production entail payments based on output, intermediate input use or capital input use granted to increase commercialisation. The information on the respective domestic support dates from 2001 and is derived from documentation provided in Jensen (2003), with corresponding subsidy rates entirely financed from the CAP budget.

${ }^{31}$ Romania is in the privileged position of having received generous quotas that consider the market potential capacity and not current levels. For example, Romania's current volume of marketed raw milk is much lower than the milk quota of approximately 3.1 million tonnes that the country obtained and that targets only direct sales and deliveries (Schroeer, 2004b). This is because although Romania currently produces around 5.1 million metric tonnes of milk (FAOSTAT, 2004), not more than 50 percent is processed by plants and/or sold directly to the market, the rest being mostly used for family/ subsistence consumption (Leat and van Berkum, 2003). For sugar, Romania also obtained generous quotas that fully cover domestic consumption, as well as its expected growth to levels comparable to that of the EU average (Cionga, 2004).
} 
support) measures considered in the alternative scenario have been explicitly considered in the model. These refer to the transfer of tariff revenue raised by Romania on agro-food imports from non-EU members to the CAP budget, the financing of agri-food export subsidies, of the single-farm (direct) payment and of other domestic support related payments from CAP budgetary resources.

\section{CGE Estimates}

Romania's accession to EU's Common Agricultural Policy will result in complex economic interactions between the supply and the demand of domestic and imported agro-food commodities and between various factor inputs across both agro-food sectors and the overall economy. ${ }^{32}$ The CGE estimates are discussed with reference to changes in three main inter-related economic variables: trade effects, production effects and welfare/real income effects.

The overall economic impacts of CAP accession on the Romanian agro-food sectors depend on the type and size of shocks entailed by the integration process. In order to identify how and to what extent assumed policy changes pertaining to the "accession-on" scenario may influence modelling outcomes, these have been grouped into five main simulations that are sequentially implemented in the model and that gradually build up to the final alternative scenario. This results in a stepwise approach to explaining modelling results, which represents a particular feature of this paper. The five main simulations refer to the unilateral liberalisation in terms of tariffs applied by Romanian on agro-food imports from EU-26 (S1); the full liberalisation of reciprocal agro-food trade between Romania and the EU, in terms of import tariffs, export subsidies, and non-tariff barriers (S2); the formation of a customs union with the EU-26 including the adoption of EU's Common External Tariff and the CAP's export subsidy rates vis-à-vis non-EU trading partners (S3); the formation of a customs union with the EU and the implementation by Romania of the single farm payment scheme (S4); and the implementation of the complete alternative accession scenario that entails, in addition to the fourth simulation, the adoption of other agricultural domestic forms of support coupled to production volumes other than direct payments (S5).

\footnotetext{
${ }^{32}$ The implementation of the CAP bundle of measures has been modelled by running separately several simulations, representing major CAP-related policy changes, which permits the modeller to adopt a stepwise approach when explaining final results. However, this paper focuses mostly on final outcomes, and only a sub-set of estimates are displayed and discussed across major components of the overall CAP accession scenario.
} 


\section{A. Impacts on trade}

A unilateral elimination of tariffs on agro-food trade with the EU translates into lower import prices, an increase in imports from EU-26 countries, and a decrease in imports from the rest of the world (table 1, column S1) ${ }^{33}$ Agro-food imports from EU-26 almost double and respectively, increase threefold, whereas imports from non-EU members decline by around 20 percent, and respectively 50 percent. The increase in imports is positively correlated with three main factors: the assumed tariff cut (that feeds into import prices), Armington elasticity of substitution values, and the calibrated share of imports in aggregate demand. Exports are impacted only indirectly through changes in import-competing sectors, hence the small change in this variable.

The removal of remaining tariffs by EU countries on agro-food imports from Romania will induce an increase in export prices and an expansion of Romanian exports (table 1, column S2). Exports with the RoW region decrease, being replaced by trade flows with the EU-26. The resulting increase in export-driven output and welfare creates greater demand for intermediate and final consumption of goods, including imported agro-food products. However, this is counteracted by the elimination of EU export subsidies, particularly in the case of food commodities (sugar, dairies, bovine meat) and the associated increase in import prices for Romania, leading to an overall decline in food imports from the EU. Moreover, further stimulus for increased trade is provided by the partial removal of non-tariff barriers. The implementation of EU's Common External Tariff rates results in a net increase of agro-food imports from non-EU members (table 1, simulation S3), implying that Romania applies significant pre-union border protection rates for agricultural and food processing sectors. The adoption of CAP's export subsidy levels stimulates export intensification with the RoW for the relevant protected agro-commodities. However, the overall net effect on agro-food exports to non-EU countries is still negative relative to the baseline scenario. The introduction of the single-farm payment and of other production subsidies (table 1, columns S4 and S5) does not significantly alter trade patterns. This is attributed to both the nature and relatively low subsidy rates being implemented, and the weak

\footnotetext{
${ }^{33}$ The volume of imports increases as a response to cheaper imports, unless import-competing domestic producers are able to rapidly adjust and reduce their prices by absorbing lower profits and increasing their efficiency (Morrissey et al, 2005). In other words, the realistic assumption made here is that the Romanian agrarian sector is not sufficiently efficient and flexible to correspondingly react to cheaper imports.
} 
Table 1. Economic impacts of Romania's accession to the CAP (percentage changes relative to the baseline)

\begin{tabular}{|c|c|c|c|c|c|}
\hline Impacts on Trade & S1 & S2 & S3 & S4 & S5 \\
\hline \multicolumn{6}{|l|}{ Trade with the EU-26 } \\
\hline Total Agricultural Exports & 7.6 & 146.7 & 138.8 & 136.5 & 139.4 \\
\hline Total Agricultural Imports & 75.4 & 101.9 & 83.6 & 85.7 & 85.7 \\
\hline Total Food Exports & 0.3 & 214.1 & 213.4 & 211.7 & 210.3 \\
\hline Total Food Imports & 227.5 & 204.0 & 221.0 & 224.3 & 226.6 \\
\hline \multicolumn{6}{|l|}{ Trade with the RoW } \\
\hline Total Agricultural Exports & 8.1 & -53.8 & -30.8 & -31.5 & -31.1 \\
\hline Total Agricultural Imports & -17.8 & 4.2 & 20.5 & 21.9 & 21.5 \\
\hline Total Food Exports & -0.2 & -36.7 & -26.2 & -26.6 & -27.1 \\
\hline Total Food Imports & -52.3 & -48.0 & -43.4 & -42.8 & -42.4 \\
\hline
\end{tabular}

Source: Author's modelling results;

Notes: S1 to S5 refer to the simulation scenarios explained in the text at the start of section VI

integration of domestic production into trade structures.

Hence, it is worthwhile emphasising that, changes in agro-food trade patterns appear to be mainly driven by trade-related CAP measures, i.e. the formation of a customs union, within which the reciprocal elimination of trade distortions plays a significant role. Agro-food trade is predicted to greatly intensify, particularly with the EU-26 members. Agro-food exports to EU-26 increase almost 2.5 times, and respectively, 3.1 times, whereas agricultural and food imports from EU-26 countries increase by around 85 percent, and respectively, 226 percent (to the detriment of trade with non-EU countries). The agro-food trade balance improves with CAP accession, and Romania becomes a more significant net-exporter of particularly commodities that were faced with substantial trade restrictions prior to accession (e.g. wheat, other cereal grains, ruminants, bovine meat, dairies, and sugar). ${ }^{34}$

\section{B. Impacts on production}

Results associated with a preferential unilateral trade liberalisation scenario show an output contraction in almost all agro-food sectors (table 2, column S1) and a reallocation of resources to the benefit of other industries, such as manufactures and services. Producers of refined sugar and plant-based fibres are predicted to record the largest output loss. This is largely explained by a combination of relatively high pre-union import tariff rates and high Armington elasticity values

\footnotetext{
${ }^{34}$ Estimations of changes in trade patterns across the agro-food sectors are available from the author.
} 
characterising these sectors. ${ }^{35}$ Nonetheless, some agri-food sectors (e.g. oilseeds and live animals) are able to marginally increase their output. This is mostly because the unilateral liberalisation has a lesser impact on domestic sectors, in cases where baseline import tariff rates are insignificant (e.g. zero for live animals and 7.7 percent for oilseeds). Hence, one could expect that granting European agro-food products enhanced access to the domestic market would force out of the market or alternatively to adjust their production methods to face harsher competition pressures.

Turning to the second simulation (S2) that includes in addition to S1 the elimination of border protection by EU-26 on agro-food imports from Romania, one would conclude that, overall, the greater market access-induced boost in export prospects and earnings results in output increases that outweigh the net production declines fostered by cheaper imports from the EU-26 member-partners. Aggregate farm and processed food production stand to benefit from 1 percent, and respectively, 4.7 percent growth (table 2, column S2). At a more disaggregated level, some sectors experience a more significant output expansion relative to the baseline, such as sugar, (bovine) meat products, and diaries $(36,20$, and respectively 17 percent), amongst agricultural activities. This is because changes in import prices indirectly affect producers, whereas changes in export prices directly and positively influence producer earnings causing a bigger impact upon output expansion. Furthermore, the higher the elasticity and the export share in production are, the larger is the increase in producer prices and domestic output. In addition, even though sugar beet is not externally traded, the production of this commodity does witness an expansion with enhanced access to European markets. This is because a large share of raw sugar output feeds into the production of refined sugar, which is predicted to benefit considerably from better access to EU markets. Among the losing sectors, the production of plant-based fibers and oilseeds further deteriorates, likely due to the pre-accession zero import tariff rates applied by the EU for these products that does not trigger any market access incentives.

Further output effects are induced by the alignment of Romania's border protection rates against non-EU members to EU levels. The general idea is that the production of those commodities that benefit from high CAP border protection rates is likely to record a further increase. However, in the case of Romania's agro-

\footnotetext{
${ }^{35} \mathrm{~A}$ high value for the latter implies that imports from the EU region are more likely to eliminate domestic competition due to the similarity of the commodity that allows for a smoother translation of the fall in import prices into the domestic economy and a subsequent decline in domestic producer prices.
} 
Table 2. Output effects across main modelled components of the CAP accession scenario (percentage changes relative to the baseline)

\begin{tabular}{lccccc}
\hline \multirow{2}{*}{\multicolumn{1}{c}{ Sector/commodity }} & \multicolumn{5}{c}{ Impacts on Production } \\
\cline { 2 - 6 } & $\mathrm{S} 1$ & $\mathrm{~S} 2$ & $\mathrm{~S} 3$ & $\mathrm{~S} 4$ & $\mathrm{~S} 5$ \\
\hline Total Agriculture & -1.2 & 1.0 & 0.6 & 0.8 & 1.5 \\
Wheat & -1.2 & 4.2 & 4.0 & 4.1 & 4.2 \\
Other cereal grains & -1.2 & 3.1 & 4.0 & 4.0 & 4.0 \\
Vegetables, fruits \& nuts & -1.3 & -1.8 & -1.8 & -1.6 & -1.9 \\
Oil seeds & 1.7 & -7.1 & -7.1 & -7.6 & -8.0 \\
Sugar cane \& beet & -7.8 & 9.2 & 12.3 & 12.2 & 12.3 \\
Plant-based fibers & -21.8 & -29.8 & -50.5 & -50.9 & -24.3 \\
Other crops & -3.0 & -2.4 & -3.9 & -3.7 & -2.3 \\
Cattle, sheep, goats, horses & 0.9 & 8.7 & 8.7 & 8.8 & 10.4 \\
Other animal products & 0.0 & -0.5 & -0.8 & -0.5 & -0.3 \\
Raw milk & -1.0 & 1.3 & 1.2 & 1.5 & 2.0 \\
Wool, silk-worm cocoons & -0.4 & -3.3 & -6.8 & -7.0 & -6.1 \\
\hline Total Food & -7.4 & 4.7 & 5.4 & 5.6 & 5.7 \\
Bovine, sheep, goats \& horse meat & -0.4 & 20.0 & 21.8 & 22.1 & 22.2 \\
Other meat products & -3.3 & 5.0 & 4.7 & 5.1 & 5.3 \\
Vegetable oils \& fats & -8.2 & 0.4 & 0.1 & -0.2 & -0.4 \\
Dairy products & -10.1 & 16.8 & 16.4 & 16.5 & 16.7 \\
Sugar & -28.8 & 36.4 & 46.6 & 46.6 & 46.6 \\
Other food products & -8.1 & 0.4 & 1.7 & 1.9 & 2.0 \\
Beverages \& tobacco & -4.7 & -4.3 & -5.4 & -5.1 & -5.0 \\
\hline Source: Aunyyyyyy & & & & & \\
\hline
\end{tabular}

Source: Author's modelling results

Notes: S1 to S5 refer to the simulation scenarios explained in the text at the start of section VI.

food sectors, only some of these are estimated to further benefit from the implementation of EU's common external tariff rates and export subsidy levels visà-vis trading partners from the rest of the world, namely the production of cereal grains other than wheat, bovine and sheep meat products, and raw and refined sugar (table 2, column S3). The production of other protected sensitive sectors does not increase significantly, due to either the absence of imports from RoW countries (e.g. wheat) or the very low share of trade with non-EU members in production (e.g. live animals and dairies) ${ }^{36}$ Sectors that are not supported by the CAP, and for which trade with the rest of the world is largely already liberalised, witness further

\footnotetext{
${ }^{36}$ In the benchmark year, live-animals display a share of imports from RoW in production of $0.01 \%$. Dairies display a share of imports from RoW in production of $0.2 \%$, and a share of exports to RoW in output of $0.1 \%$.
} 
output drops (e.g. plant based fibers, wool, oilseeds). ${ }^{37}$

The fourth simulation (S4) that introduces direct payments as a homogenous input subsidy to all agricultural land reduces farmers' producer costs of inputs and increases the price producers receive. However, the effect of the land input subsidy on activity level is only marginal across all agricultural sectors, with a slight increase in the overall farm production from 0.6 (in the third scenario) to 0.8 percentage changes relative to the baseline. This is due to both the relative low input subsidy rate that is being implemented (upward adjustment of 3.4 percent) and the nature of subsidy that is homogenously applied to all agricultural land irrespective of the crops produced or the type of grazing activities practiced. ${ }^{38}$ The slight increase in farm production further feeds into the increase in food production, particularly because a significant proportion of agricultural products serve as an intermediate input into food-processing industries.

The fifth simulation (S5) represents the main CAP accession scenario and introduces in addition to previous simulations other types of domestic support coupled to production volumes in line with EU levels. Granting other production related domestic support further decreases the cost of producing and favourably impacts output levels, in particular for those agricultural commodities that receive the largest subsidies, such as plant-based fibers (which are assumed to receive the highest subsidy rates of around 16 percent), other crops (3 percent subsidy rates), and live animals and wool ( 2 percent subsidy rates). These sectors improve their output prospects, though in some cases they remain negative particularly in those sectors significantly affected by EU accession, for example plant-based fibers.

Hence, Romania's agro-food sector is hypothesised to grow with accession to the CAP. At the aggregate level, agro-production is likely to increase, though moderately, by 1.5 percent relative to the baseline. Food production is hypothesised to benefit relatively more and grow by 5.7 percent. The extension of the CAP is likely to result in greater growth opportunities for producers of goods that will

\footnotetext{
${ }^{37}$ An exception is raw milk, for which production remains relatively unchanged at this point in the modelling application. Though trade in raw milk with non-EU members is already largely liberalised, the increase in diary output manages to keep raw milk production stable and compensate for any nonEU competition-driven losses.

${ }^{38}$ The modelled value of the single farm payment represents only $35 \%$ of the total value that is to be gradually implemented across a ten-year period. However, even when the land input subsidy rate is increased to 100 percent of EU level the direction of change in production pattern remains constant, whereas the corresponding magnitudes increase slightly reflecting the partial connection to output that this new scheme still maintains.
} 
particularly enjoy enhanced access to European markets and higher support levels under the CAP regime (sugar beet, bovine livestock, cereal grains, and raw milk, among agricultural commodities, and sugar, bovine meat, dairies and other meat products, among food products). In contrast, some agro-food activities in Romania, for which the EU already practises a more liberalised trade with non-members, are predicted to contract, to the benefit of the favoured sectors (e.g. plant-based fibers and oilseeds). A surprising result or at least worthwhile emphasising is the estimated significant increase in Romania's production of raw milk and dairies, and of sugar beet and sugar due to CAP adoption, ${ }^{39}$ which is in contrast to other studies predicting output contraction in these sectors (Frandsen and Jensen, 2003, Brockmeier et al, 2003, Banse, 2003). This is mainly due to the current limited marketed output for these sectors in Romania, which may not face restrictions by the corresponding quotas agreed with the European Commission and which may be able to develop to its full potential.

Considerable changes in the composition of agro-production have occurred in other countries joining the EU in the past (Spain, Greece, and Portugal), which at the time had a farming sector comparable to the current situation in Romania. ${ }^{40}$ Nonetheless, the type of products favoured under the CAP regime differed across these countries, depending on comparative advantage and the type of CAP protection measures offered at the time of accession. For instance, industrial crops (e.g. cotton, tobacco, citrus fruits) were favoured in Greece because they did not compete with EU (Zioganas, 1998). In Portugal, the area of arable land contracted in favour of area planted with permanent crops (Kuik and Oosterhuis, 2001). In Spain, CAP accession significantly challenged continental crop production (cereal, beef, dairy, sugar beet), but offered important incentives to Mediterranean crops (wine, olives, fruits, vegetables) (Gavrina, 2004).

\section{Impacts on welfare}

Welfare gains, measured by the equivalent variation $(\mathrm{EV}),{ }^{41}$ are predicted to amount to 1.8 percent of the baseline GDP, whereas earnings from factors

\footnotetext{
${ }^{39}$ Results for the sugar beet and sugar sector should be nevertheless treated with caution. This is because projected production impacts may be lower than estimated, if further liberalisation commitments, and particularly changes to the EU Sugar Regime, are to be implemented within the baseline time-scale referred to in the model.

${ }^{40}$ Before accession, Greece, Spain and Portugal also had large agricultural labour intensive sectors dominated by small private individual farms, as well as similar climatic conditions.
} 
employed in agriculture are hypothesised to increase by almost 9 percent (table $3) .{ }^{42}$ Both aggregate welfare gains and increases in farm income earnings are expected to accrue largely due to enhanced access to EU's agro-food markets (column S2 in table 3). Further positive welfare impacts are fostered by the partial removal of non-tariff barriers, the selective subsidisation of agricultural production and exports financed from the CAP budget, and the inflow of cheaper imports from the EU (the latter reflecting a slight domination of the trade creation effect over the trade diversion effect). However, estimated efficiency gains associated with reciprocal trade liberalisation are relatively small in magnitude. This is partly attributed to the fact that the bulk of bilateral trade (in particular manufactures) has already been liberalised with the implementation of the Europe Association Agreements and that most of the trade-induced gains have already been triggered during Romania's preparation process for EU accession. ${ }^{43}$ Other positive impacts on factor earnings in agriculture accrue largely from the subsidisation of production from EU sources (i.e. direct payments and other forms of domestic support linked to production volumes).

Welfare losses are mostly incurred by trade diverting effects, an increase in border protection against non-EU members for some commodities, and the transfer to the EU budget of tariff revenue resulting from importing agro-foods from the rest of the world. Negative impacts on agricultural income are mainly fostered through the unilateral liberalisation scenario (column S1 in table 3) that induces a contraction of farming output, reduced factor demand and lower earnings from factors employed in agrarian activities.

Therefore, enhanced access to European agro-food markets, in terms of a reduction in both tariff and non-tariff barriers, represents the main driver of the specialisation effects identified above and of the potential economic welfare gains.

\footnotetext{
${ }^{4}$ The equivalent variation represents the change in the original amount of income that would generate the same level of household utility as that obtained in the new equilibrium. EV is measured in the modelling literature generally as a percentage of the baseline GDP.

${ }^{42}$ Earnings from factors of production employed in agriculture are assumed to proxy agricultural income. However, factor earnings from agriculture do not necessarily equal income accruing to farmers, as these may include not only farmers' earnings but also earnings of other rural/urban land owners or land workers.

${ }^{43}$ For example, a variation of this CGE model associates stand-alone welfare gains measured by the equivalent variation of around 2.3 percent of baseline GDP with increased access to European markets for Romanian manufactures. In other words, in terms of aggregate welfare effects it seems that the trade benefits stemming from EU integration are "front-loaded" (Vanags, 2002).
} 
Table 3. Impacts on welfare and factor earnings in agriculture (changes relative to the baseline scenario)

\begin{tabular}{lccccc}
\hline & S1 & S2 & S3 & S4 & S5 \\
\hline EV (percent of GDP) & 0.2 & 1.3 & 1.1 & 1.5 & 1.8 \\
EV (constant 1997 billion ROL) & 747.1 & $4,469.7$ & $3,721.4$ & $5,333.8$ & $6,185.5$ \\
Factor earnings in agriculture (\%) & -1.4 & 5.9 & 5.9 & 7.6 & 8.7 \\
$\begin{array}{l}\text { Factor earnings in agriculture } \\
\text { (constant 1997 billion ROL) }\end{array}$ & -942.6 & $3,879.8$ & $3,890.7$ & $4,963.5$ & $5,697.6$ \\
\hline
\end{tabular}

Source: Author's AGE modelling results

Notes: S1 to S5 refer to the simulation scenarios explained in the text at the start of section VI.

The results are in line with Wonnacott and Wonnacott (2005), who argue that in a tariff-ridden world, gains for a country joining a customs union can be attained not only through unilateral tariff reductions, but also through the removal of foreign tariffs, improved terms of trade, and better access to the partners' foreign markets. This is emphasised in the case of small open economies that are able to improve their terms of trade, by being offered a better price with the elimination of foreign barriers on their exports, than would be the case should they act on their own as price takers. ${ }^{44}$ In other words, the modelling results confirm the theoretical argument that the terms of trade effect due to increased foreign market access may bring significantly higher welfare gains than those induced by the preferential unilateral liberalisation.

\section{Concluding Remarks}

This paper has evaluated the potential economic impacts of Romania's adopting the EU's Common Agricultural Policy through the deployment of a CGE model and the adoption of a step-wise approach to explaining results. Most of the CGE literature investigating the effects of CAP accession on candidate countries has focused on the ten Central and Eastern European countries that have joined the EU in 2004. In addition, CGE studies that have considered the effects on Romanian agriculture are sparse and tend not to give sufficient consideration to the specific conditions and circumstances under which Romania joined the EU.

Three main findings emerge. First, CAP accession will increase overall private

\footnotetext{
${ }^{44}$ However, enhanced market access opportunities could have been even greater for these sectors if they would have been better integrated into international trade structures and would have displayed higher export shares
} 
welfare, expand agro-food output and trade, and promote overall higher farm incomes. This finding is not necessarily surprising and is in line with other studies arguing that CAP implementation in the CEE region is likely to increase farm income and encourage agricultural growth in accession countries. Second, specialisation effects are revealed particularly for the production of sugar and sugar beet, (bovine) meat products, ruminant live animals, dairies, and cereal grains. This outlines the likely change in the disposition of agro-food output specific to the case of Romania. A surprising finding is that output for sugar and diaries is estimated to significantly expand with EU accession, which is contrary to results from previous studies, which find that this is generally quota-restricted in most accession economies. And third, the identified impacts are driven mostly by changes in traderelated measures, especially enhanced access to EU markets, and less by alterations in production related domestic support, which has been redesigned and reduced with recent CAP reforms. Again this is a result worthwhile emphasising, since it shows that gains from adopting the CAP are more likely to result from greater trade integration with EU countries and increased market access, than merely due to Romanian agro-food producers benefiting from greater subsidy levels.

However, these medium-term post-accession projected gains may occur only if the main modelling assumptions are illustrative of reality. The model may face both overestimation and underestimation problems driven by assumptions pertaining to the size and type of shocks applied, calibrated and assumed model parameters (e.g. Armington elasticities), and model formulation (e.g. static versus dynamic, imperfect versus perfect competition). In addition, and (arguably) most importantly, the CGE model employed in this paper implicitly assumes that domestic producers are able to respond to the price and supply incentives provided under the CAP umbrella. However, this is unlikely to hold in the case of Romanian agriculture, particularly during the first years of membership, due to the significant structural and institutional constraints inherited or developed during the country's transition and reform process. The modelling results reported in this paper, therefore, should not be regarded as forecasts or precise estimates. These findings are only intended to render a sense of the order of magnitude of the relative potential changes in output and trade patterns, and to provide useful insights for policy making targeting agricultural development.

Adhering to the CAP may bring growth in Romania's agro-food sector, but in practice this will depend on producers' ability to reply to the supply incentives being offered. Policy makers need, therefore, to bear in mind that policy 
intervention should foremost deal with factors inhibiting agro-food producers' supply response potential, so that they are in a more favourable position to respond to increasing competition, capitalise on enhanced market access, and thereby benefit from integration into the CAP. Adopting EU's Common Agricultural Policy, and gaining greater access to European markets, may prove a necessary but not sufficient condition for effectively harnessing agricultural development in Romania.

\section{Acknowledgments}

I am indebted to Adam Blake, Colin Kirkpatrick and Clive George for valuable comments on an earlier version of the paper. I am also grateful to the anonymous referee and to the editor of this Journal for useful suggestions and comments. The author is solely responsible for all remaining errors and shortcomings.

Received 9 May 2006, Accepted 13 September 2006

\section{References}

Banse, M. (2001). Study on the Disaggregation of the GTAP Database for the Countries of Central and Eastern Europe, Final Report ref.2000/S 136-088749 for the European Commission

Banse, M. (2003). CAP and EU Enlargement, paper presented at the USDA/ Farm Foundation Conference on 'WTO: Competing Trade Policy Issues and Agendas', September 17, Washington, D.C.

Blanchflower, D. (2001). Unemployment, Well-Being, and Wage Curves in Eastern and Central Europe, Journal of the Japanese and International Economics, 15(4): 364402.

Brockmeier, M., Herok, C., von Ledebur, O. and Salamon, P. (2003). EU Enlargement a New Dimension, paper presented at the 25th Conference of the International Association of Agricultural Economists, August, 16-22, Durban (South Africa).

Cionga, C. (2004). Romania: Accession Talks on Agriculture Completed 2004, GAIN report no. RO4013, Washington, Foreign Agricultural Service, US Department of Agriculture.

Ciupagea, C., Marinas, L., Turlea, G., Unguru, M., Gheorghiu, R. and Jula, D. (2004). A Cost-Benefit Assessment of Romania's Accession to European Union, Study no.12, Pre-accession Impact Studies II, Bucharest, European Institute of Romania.

Donnelly, W., Ingersoll, D., Johnson, K. and Tsigas, M. (2004). Revised Armington Elasticities of Substitution for the USITC Model and the Concordance for 
Constructing a Consistent Set for the GTAP Model, Office of Economics Research Note No.2004-01-A, Washington, United States International Trade Commission.

EC (1999), Europe's Agenda 2000. Strengthening and Widening the European Union, Draft of Commission information brochure for the general public on Agenda 2000, Priority Publication programme 1999, X/D/S, final version 31.8, Brussels: European Commission.

EC (2002). Agricultural Situation in the Candidate Countries. Country Report on Romania, Brussels, Directorate General for Agriculture, European Commission.

EC (2003a). EU Fundamentally Reforms Its Farm Policy to Accomplish Sustainable Farming in Europe, EC press release IP/03/898 (26/06/2003), Brussels: European Commission.

EC (2003b). Report on the Results of the Negotiations on the Accession of Cyprus, Malta, Hungry, Poland, the Slovak Republic, Latvia, Estonia, Lithuania, the Czech Republic and Slovenia to the European Union, Brussels: European Commission.

FAO (2003). WTO Agreement on Agriculture: The Implementation Experience Developing Country Case Studies, Rome, Food and Agriculture Organisation of the United Nations.

FAOSTAT data (2004). FAO Statistical Databases, online resource: http://faostat.fao.org/, Food and Agriculture Organisation of the United Nations (last accessed April 2004).

Frandsen, S., Jensen, H. and Vanzetti, D. (2000): Expanding 'Fortress Europe': Agricultural Trade and Welfare Implications of European Enlargement for NonMember Regions, World Economy, 23(3): 309-329.

Fuller, F., Beghin, J., Fabiosa, J., Mohanty, S., Fang, C. and Kaus, P. (2002). Accession of the Czech Republic, Hungary and Poland to the European Union: Impacts on Agricultural Markets, World Economy, 25(3): 407-428.

Gavrina, H. (2004). Learning from Previous Experience: CAP and Agriculture in Spain, in Konecný, M. (ed.) The CAPacity Building Manual, Brussels, Friends of the Earth Europe, section 13.

Government of Romania (2004). Romania - Letter of Intent, Memorandum on Economic and Financial Policies, and Technical Memorandum of Understanding, Governmental Report to the International Monetary Fund, Bucharest, Government of Romania.

Hertel, T. W. (1999). Applied General Equilibrium Analysis of Agricultural and Resource Policies, GTAP Working Paper no.03, West Lafayette, Center for Global Trade Analysis, Department of Agricultural Economics, Purdue University.

Hertel, T. W., Brockmeier, M. and Swaminathan, P.W. (1997). Sectoral and EconomyWide Analysis of Integrating Central and Eastern European Countries into the EU: Implications of Alternative Strategies, European Review of Agricultural Economics, 24(3/4): 359-396.

Herok, C. and Lotze, H. (2000). Implications of an EU Eastern Enlargement under a New Common Agricultural Policy, Journal of Policy Modeling, 22(6): 661-690.

Hertel, T. W., and Tsigas, M. (2002). Other Source Data: Primary Factor Shares, in 
Dimaranan, B. V. and R. A. McDougall (eds.) Global Trade, Assistance, and Production: The GTAP 5 Data Base, West Lafayette, Center for Global Trade Analysis, Purdue University, chapter 18.C.

IISD (1994): Making Budgets Green. Leading Practices in Taxation and Subsidy Reform, Winnipeg: International Institute for Sustainable Development.

Jensen, H. (2003). Dis-Aggregating the EU15 Domestic Support, GTAP Resource no.1388, West Lafayette, Center for Global Trade Analysis, Purdue University.

Jensen, H. and Frandsen, S. (2003). Implications of EU Accession of Ten New Members: The Copenhagen Agreement, Working Paper no.01/03, Copenhagen, Danish Research Institute of Food Economics.

Jensen, H., Frandsen, S. and Bach, C. (1998). Agricultural and Economy-Wide Effects of European Enlargement: Modeling the Common Agricultural Policy, Working Paper no.11/1998, Copenhagen, Danish Research Institute of Food Economics.

Kallai, E. and Traistaru, I. (1998). Characteristics and Trends of Regional Labour Markets in Transition Economies: Empirical Evidence from Romania, LICOS Discussion paper no.72/1998, Leuven, Centre for Transition Economies, Katholieke Universiteit Leuven.

Kelch, D., and M. A. Normile (2004). CAP Reform of the 2003-04, USDA report no. WRS-04-07, Washington DC: Economic Research Service, United States Department of Agriculture.

Kuik, O. and Oosterhuis, F. (2002). Lessons from the Southern Enlargement of the EU for the Environmental Dimensions of Eastern Enlargement, in particular for Poland, Working Paper no.59, Milan, Fondazione Eni Enrico Mattei.

Leat, P. and van Berkum, S. (2003). Dairy Sector Analysis, in van Berkum, S., S. Davies, and S. Popov (eds.) The Romanian Agrifood Chain: On the Road to Accession, Bucharest, Ministry of Agriculture, Forests, Water and Environment, 15-48.

Liapis, P. and Tsigas, M. (1998). CEEC Accession to the EU: A General Equilibrium Analysis, in Burfisher, M. and E. Jones (eds.) Regional Trade Agreements and U.S. Agriculture, Agricultural economics report no. 771, Washington, Economic Research Service, U.S. Department of Agriculture, chapter 5.

Lips, M. and Rieder, P. (2005). Abolition of Raw Milk Quota in the European Union: A CGE Analysis at the Member Country Level, Journal of Agricultural Economics, vol. 56(1): 1-16.

Maliszewska, M. (2002). Eastern EU Expansion: Implications of the Enlarged Single Market for Current and New Member States, paper presented at the GTAP 5th Annual Conference on Global Economic Analysis, June 5-7, Taipei.

Morrissey, O., te Velde, D., Gillson, I. and Wiggins, S. (2005). Sustainability Impact Assessment of Proposed WTO Negotiations: Final Report for the Agriculture Sector Study, London/Manchester, ODI, IIED and Institute for Development Policy and Management, University of Manchester.

NBR (2004). Annual Report 2003, Bucharest, National Bank of Romania.

NIS (2004). Romanian Statistical Yearbook, 2003. Time Series: 1990-2002, CD-ROM, 
Bucharest, National Institute of Statistics (NIS).

OECD (2002). Agricultural Policies in Transition Economies: Trends in Policies and Support, Paris, Organisation for Economic Co-operation and Development.

OXFAM (2002): Boxing Match in Agricultural Trade: Will Wto Negotiations Knock out the World's Poorest Farmers?, Oxfam briefing paper 32, Oxford: Oxfam.

Petersen, T. (1997). An Introduction to CGE-Modelling and an Illustrative Application to Eastern European Integration with the EU, Working Paper 4, Copenhagen, Institute of Economics, University of Copenhagen.

Philippidis, G. and Hubbard, L.J. (2003). Agenda 2000 Reform of the CAP and its Impacts on Member States: A Note, Journal of Agricultural Economics, vol.54(3): 479-486.

Piazolo, D. (1999). Welfare Effects Versus Income Effects of Poland's Integration into the European Union, Kiel Working Paper no.940, Kiel, Kiel Institute for World Economics

Pirzio-Biroli, C. (2002). The Present and Future CAP, opening address at EU/ICC Cereals Conference 2002, 7 March, Vienna.

Schroeer, L. (2004a). EU-25 Trade Policy Monitoring: CAP Reform 2003 Deconstructing Decoupling 2004, GAIN report number E34044, Washington: Foreign Agricultural Service, United States Department of Agriculture.

Schroeer, L. (2004b). EU-25 Agricultural Situation: Agriculture Talks End for Romania and Bulgaria 2004, GAIN Report Number E34028, Washington, Foreign Agricultural Service, United States Department for Agriculture.

Scottish Office (1999). The Common Agricultural Policy Factsheet, Edinburgh: Agriculture, Environment and Fisheries Department, The Scottish Office.

Scrieciu, S. (2007). The inherent dangers of using computable general equilibrium models as a single integrated modelling framework for sustainability impact assessment. A critical note on Böhringer and Löschel, Ecological Economics, Vol.60(4): 57-76.

SER (1996). Reform of the Common Agricultural Policy, Advisory Report, The Hague: Social and Economic Council (SER) in the Netherlands.

Söderstern, B. and Reed, G. (1994). International Economics. Basingstoke, Macmillan.

Strossman, C. (2004). EU-25 Agricultural Situation: Enlargement of the Common Agricultural Policy 2004, GAIN report no. E34004, Washington: Foreign Agricultural Service, United States Department for Agriculture.

The Economist (2002). The EU's Agricultural Policy: Reform? Forget It. The Latest Plan to Revamp Europe's Farm Policy Looks Stymied, for Now, The Economist, October, 3.

Vanags, A. (2002). The Economic Impact of EU Accession for Latvia: A Computable General Equilibrium Approach, Riga, Baltic International Centre for Economic Policy Studies.

Walsh, P. and Duffy, F. (2002). Individual Pay and Outside Options: Evidence from the Polish Labour Force Survey, CERT Discussion Paper no.0201, Edinburgh, Centre for Economic Reform and Transformation, Heriot Watt University.

Wonnacott, P. and Wonnacott, R. (2005). What's the Point of Reciprocal Trade Negotiations? Exports, Imports, and Gains from Trade, The World Economy, 28(1): 
1-20.

Zalai, E. (1998). Computable Equilibrium Modelling and Application to Economies in Transition, CERT Discussion Paper no. 9804, Edinburgh, Centre for Economic Reform and Transformation, Heriot Watt University.

Zioganas, C. M. (1998). The Organisation of Primary Agricultural Production in Greece: Evolution and New Challenges for Re-Orientation, in Lekakis, J. N. (ed.) Freer Trade, Sustainability, and the Primary Production Sector in the Southern EU: Unraveling the Evidence from Greece, Dordrecht, Kluwer Academic Publishers, 1932. 